\title{
The Current Situation of Pastoral Programs in the Prisons in Western Kenya Counties
}

\author{
Leakey Mokua Nyaberi", Susan Kilonzo, Sussy Gumo
}

Department of Religion, Theology and Philosophy, Maseno University, Kenya

Copyright $\bigcirc 2019$ by authors, all rights reserved. Authors agree that this article remains permanently open access under the terms of the Creative Commons Attribution License 4.0 International License

\begin{abstract}
Crime generates underestimated substantial costs to society at the individual, community and national levels. Globally, governments use prisons to contain crime. The criminal justice system has two primary goals: justice and a more prominent goal of preventing future crimes by incapacitation, deterrence, and rehabilitation. Globally, a number of prisons have set up pastoral programs to give inmates realistic plans for their lives, as well as help them overcome shame and guilt and help provide a meaningful human service. This paper examines the current situation of pastoral programs in the prisons in western Kenya Counties. Specifically, the paper examines gender, denomination, educational qualifications, training experiences, salaries, ordination, places of worship, chaplaincy offices, counselling schedule, residential facilities and funding of chaplaincy in the Prisons of Western Kenya Counties. The chaplain-catechists questionnaire was administered to the chaplains and catechists and their responses consisted their background information, roles in rehabilitating inmates, as well as their training and living conditions. The Focus Group Discussion (FGD) guide was administered to the inmates and officers-in-charge. We conclude that although the Kenya Government has tried to improve on the status of issues raised in chaplaincies, more has to be done to achieve standards that can enable effective chaplaincy in prisons in western Kenya.
\end{abstract}

Keywords Prison, Chaplaincy, Crime, Church, Western Kenya

\section{Introduction}

Studies have shown that as many as $60-75 \%$ of those released from prison will be back behind bars within four years of release (Pace, 1982; Sharp, 1977; Rabey, 1999; Ristard, 2008). Rabey (1999) contends that in many cases, these men, women, and Juveniles have neither the desire nor the ability to become productive members of the society. Despite the high rates of recidivism, the use of religion as a rehabilitative program or treatment is commonplace in jails and prisons throughout the world. Dammer (2002), states that $32 \%$ of inmates are involved in religious activities such as church attendance, prayers, and other religious activities. Previous research has shown that religion even surpasses education as most frequently represented program in jails and prisons throughout the United States (Johnson, 2008). Religion for the prison chaplains is an essential part of rehabilitation for inmates as it acts as a bridge between prison and society. For the chaplains, instilling religious values reinforces their objective of teaching inmates to find value in their lives, and from this, new found self-esteemed individuals will be able to become productive citizens. The chaplains firmly believe that through their work and through the care that they exert, they can help inmates build pious characters. Religion can give [inmates] a direction, which in turn can guide them towards reaching their life goals. It can also change how they see themselves and others in society. We need to learn to be humble and respect others (Chui and Cheng, 2011). A study done by Sundt and Cullen (2002) found that chaplains were overwhelmingly supportive of rehabilitation and the treatment of prisoners, although they acknowledge that the goal of prisons is primarily incarcerating offenders for the protection of society. The work of the prison chaplain in thus seen in offering assistance, which contrasts with the control setting of the prison, one of which the chaplains are well aware.

Evidence of the acceptance of religion in correctional institutions is also supported by the growth of prison ministry programs. One such program is the Prison Fellowship Program (PF) founded by Charles Colson in 1975 (Dammer, 2002), the other being The Abdi Sabda Team Ministry in Indonesia established in 1992 to cater for juvenile prisoners and those yet to be sentenced (Sihombing, 2010). In their study, Tewksbury and Collins (2005) noted that almost all volunteers report that they engage in some form of teaching inmates. The most frequently reported "formal" activity that volunteers engage in is preaching at the prison; fully two-thirds $(65.9 \%)$ of the volunteers report doing so. Interestingly, relatively few of the volunteers report that they engage in 
tasks not of a purely religious nature, such as counseling regarding personal problems, assisting with transition/re-entry to society, and providing companionship/friendship to inmates.

The influence of religion as a treatment alternative in prison is as old as the history of Prisons. The early Christian Church beginning in the days of Constantine granted asylum to criminals who would otherwise be mutilated or killed (Dammer, 2002). Soon thereafter imprisonment under Church jurisdiction became a substitute for corporal punishment. In medieval times, monastic cells served as a place of punishment of troublemakers (Hoyles, 1955). Formally-organized ministry to prisoners begun in 1488 when the Order of Misericordia (Beheading of St. John) was established for its members to assist and console criminals condemned to death (Keuther, 1951). English reformers established similar ministries for prisoners during the 16thC (McNeill, 1951; Korn, 1959). Americans brought with them the laws of England hence punishment by humiliation through "stocks and the whipping post" (Dammer, 2002).

With the coming of colonialists, the European systems of criminal law and penal practices were imposed on Africa to serve European objectives (Milner, 2012). These imposed legal systems, codes, procedures, institutional practices and expatriate administrative and penal officers remain a major influence on African penal systems (Milner, 2012). Prison conditions in Africa during this time were said to be reasonably comfortable in terms of availability of water, food in quantity and at regular times, healthy conditions and availability of medical help. The majority of the convicts were undoubtedly better off in prison than they would have been in their own homes (Milner, 2012). The same cannot be said of African prisons today. According to Victor Dankwa (2008), overcrowding is a major problem in most African prisons. Consequently, this dehumanizes prisoners; renders unattainable international standards relating to hygiene, sanitation, sufficient food and accommodation which in turn encourages illicit sexual relations to name but a few (Amoakoh, 2012). Although studies like Amoakoh's are important in giving us the contexts within which prisoners live, they do not highlight the role of religion, and specifically chaplaincy, in addressing these hardships.

It is against this background that this article set to examine the current situation of pastoral programs in the prisons in western Kenya Counties. Specifically, the paper examines gender, denomination, educational qualifications, training experiences, salaries, ordination, places of worship, chaplaincy offices, counselling schedule, residential facilities and funding of chaplaincy in the Prisons of Western Kenya Counties.

\section{Methods}

\section{Research Design}

The research design adopted for this study was the descriptive survey. Surveys are useful in establishing the existing conditions of a phenomenon (Frankel and Wallen, 1999). This design was supplemented by quantitative measures to explain certain aspects that cannot be addressed using descriptive measures only. The research design enabled detailed investigation of the role of pastoral programs in rehabilitating long-term Christian inmates. The study employed both quantitative and qualitative methods. The advantage of this mixed method research is that it provides strength that offset the weaknesses of both qualitative and quantitative research and it offers a comprehensive evidence for studying a research problem than either qualitative or quantitative alone (Kothari, 2004). Quantitative study design using in-depth interviews and focus group discussions (FGDs) were used to generate data. The use of qualitative method in form of oral interviews was also appropriate for this study as it facilitated the gathering of narratives and experiences related to prisoners.

\section{Study Area}

The study was carried out in 4 counties of the former Western Province. The four counties of the Western Region are Kakamega, Busia, Bungoma, and Vihiga. Western Kenya region has 27 administrative districts and 26 constituencies distributed as follows; Kakamega County (9 constituencies), Vihiga (4 constituencies), Bungoma (6 constituencies) and Busia (7 constituencies). There are 7 prisons distributed as follows Kakamega (4), Vihiga (1), Bungoma (1) and Busia (1) with a population of 3484 inmates (Prisons Headquarters, December 2012). Of these inmates 1314 are long-term ( 3 years and above), 913 are short-term ( 0 - 3 year), 593 are ordinary remands waiting for trial or unable to raise bonds and 654 are capital remands (Prisons Headquarters, December 2012). There are 3 civil debtors, 6 mental patients, and 26 children (4 years and below) accompanying their mothers in prison making a grand total of 3484 inmates. Every prison is expected to have at least 4 chaplains representing Roman Catholics, Protestants, Seventh-day Adventists and Muslims. There are several prisons guards and one officer who oversees every prison.

\section{Sampling Procedure}

The sample for this study was selected using cluster and purposive sampling to ensure a balance of group sizes when multiple groups are to be selected (Black, 1999). Cluster sampling and purposive random sampling techniques were employed to select 387 long-term inmates from 6 prisons of the Western Kenya Counties. Purposive sampling was used to select 16 chaplains and 301 inmates. A total of 72 respondents [63 long-term Christian inmates (LTCIs), 1 officer-in-charge (OIC), 3 chaplains/catechists $(\mathrm{C} / \mathrm{C})$, and 5 prison guards (PGs)] from Busia prison were 
used for pilot study and did not, therefore, form part of the actual study.

\section{Methods of Data Collection}

The study obtained data for analysis through questionnaires, interview, focus group discussion (FGDs) and observation. Two sets of questionnaires were constructed for purposes of collecting data. They were administered to: Chaplains/Catechists Questionnaires (CCQ), and Christian Long-term Inmates questionnaires (CLTIQ). The questionnaires contained both open- and closed-ended questions. A face-to-face interview was conducted on 5 Officers in Charge of Prisons in the Counties (ISOIC) and 21 Chaplains of Western Kenya. The FGDs were held in each purposively selected prison resulting in a total of 301 inmates, who volunteered to participate in the discussion. The prisons were purposively selected so that they are representative of the four main categories of prisons in Kenya. Direct observation of prisons physical facilities, worship tools and worship environment, and Chaplaincy facilities, in general, were observed. Participant observation was used to enable the researcher record the natural behaviour of inmates in the selected prisons.

\section{Results and Discussions}

\section{Current Situation of Chaplaincy in Western Kenya Counties}

Researchers have associated pastoral programs in prisons with several uses. For instance, Allard (2010) noted the aim of prison chaplaincy as focusing on pastoral care and counselling, preaching, listening, and accompanying inmates in the transformation journey. According to Duncombe (1992), prison chaplaincy should give inmates realistic plans for their lives, as well as help them overcome shame and guilt. In Kenya, the mandate to have pastoral programs in prisons has been documented (Kenya Prison Service, 2012). Finding out the current situation of chaplaincy in Kenyan prisons is important as it would provide insights into how pastoral care can be improved to give chaplains "a stronger prophetic voice on issues that affect inmates and help provide a meaningful human service" in the prisons (Akih and Dreyer, 2012).

\section{Gender of Chaplains}

Both male and female work as chaplains in prisons in western Kenya. However, it was noted that most people who volunteer to work as chaplains in prison are men as compared to female. The low number of women who work as chaplains in prisons are deployed by their member churches. Otherwise they would not be willingly work as chaplains in prisons for fear of attack from the inmates. Majority of male working as chaplains felt that it was a calling for them to bring some changes to the inmates hence volunteered for the work. However, some male chaplains were posted by their mother churches. Table 1 below shows the distribution of gender among the chaplains.

Table 1. The Gender of Chaplains

\begin{tabular}{ccc}
\hline & Frequency & $\mathbf{\%}$ \\
\hline Male & 12 & 75.0 \\
\hline Female & 4 & 25.0 \\
\hline Total & $\mathbf{1 6}$ & $\mathbf{1 0 0 . 0}$ \\
\hline
\end{tabular}

Source: Field data

It can be observed from Table 1 that there were 12 (75.0\%) male and $4(25 \%)$ female chaplains. A study done by Tewksbury and Dabney stated that the volunteers gave diverse reasons for participating in the prison ministry program. Although $49.2 \%$ of the respondents said they had "a religious calling or desire to share religious beliefs/values with others," $26.2 \%$ expressed non-religious reasons, and $18 \%$ participated in the program because they were asked to do so or because they knew someone who was incarcerated (3\%) (2004:176). Many volunteers stated that the most rewarding aspect of their prison experience was the belief in their work and that they could make a difference. Reflective of this, Tewksbury and Dabney (2004) reported that male volunteers were more likely than women $(41.9 \%$ vs. $30.8 \%)$ to value feeling that they were helping to change/rehabilitate inmates, while women were more likely than men $(23.1 \%$ vs. $3.2 \%)$ to value the opportunity to share a religious experience with others.

\section{Denomination of Chaplains}

A chaplain may come from any denomination or religion. However, it was noted that majority of the chaplains serving as Prison Chaplains in Western Kenya are seconded by their various Christian churches to serve as ministers of faith in various prisons. The study revealed that most of the prison chaplains come from the Roman Catholic Church, various Protestant Churches and Seventh Day Adventists. Table 2 below shows the distribution of chaplains across denominations.

The Roman Catholics and Protestants inmates had 6 $(37.5 \%)$ chaplains each while the SDAs had $4(25 \%)$ chaplains. Apparently, some prisons studied lacked denomination specific chaplains. For example, some prisons did not have an SDA chaplain at all. In a prison that lacked a catholic chaplain, the inmates themselves led the worship services. Whereas data in Table 2 revealed that there were more Protestant Christians in the Counties of Western Kenya prisons 183 (60.8\%) compared to Catholics who were $74(24.6 \%)$, they all had the same number of chaplains. This meant that the Protestant Christians who 
are the majority in the prisons of Western Kenya counties were clearly underrepresented. A study done by Phew Research Centre showed that the chaplains' estimates of the religious affiliation of inmates are, at best, a very rough indicator. But the estimates suggest that most inmates in state prisons are Christians, albeit with substantial numbers of Muslims, followers of pagan or earth-based religions, practitioners of Native American spirituality and inmates not affiliated with a religion (Phew Research Centre, 2012). It also meant that such a situation lead to inmates not getting pastoral services even though the Kenya Prison Service (2012) uses religious activities as a rehabilitation tool which in turn may negatively affect the effectiveness of rehabilitation services.

Table 2. Denomination distribution of Chaplains

\begin{tabular}{ccc}
\hline & Frequency & $\mathbf{\%}$ \\
\hline Roman Catholic & 6 & 37.5 \\
\hline Protestant & 6 & 37.5 \\
\hline SDA & 4 & 25.0 \\
\hline Total & $\mathbf{1 6}$ & $\mathbf{1 0 0 . 0}$ \\
\hline
\end{tabular}

Source: Field data

A similar observation was made by Duncombe (1992) and Akih and Deyer (2012) where governments recognize the importance of pastoral programs in prisons but are unable to support these programs so that they are effective in addressing the needs of the inmates. For instance, Duncompe (1992) noted how rehabilitative programs are sometimes scarce and non-existent and how this situation leaves inmates without proper support during their time of incarceration.

From the findings of the survey conducted among the inmates during the FGDs the inmates stated that they normally see the chaplain occasionally like when they have guests or when he wants to come for preaching. They claimed that it's their wish to meet the pastor to share their story, but every time he comes, he is in a hurry to go and worship in the local church. The fact that he also does not have an office attributes to his ever absence from the prisons to meet the inmates.

Yet another inmate had the following to say:

Mate 11. I have had the opportunity to work closely with my chaplain for several years as a spiritual leader, the major problem is not availability because on Monday he has a day off, Tuesday he is supposed to meets us in the wards, but most of us are out in industries or in the farms working, moreover the wards are many and inmates too many for one person.

Table 3 demonstrates the denominations of the 301 inmates included in the study.

Results shows that there are $183(60.8 \%)$ Protestant inmates in the counties of western Kenya prisons, 74(24.6\%), Roman Catholics and 44 (14.6\%) Seventh Day Adventists. The Protestant Christian inmates appear to be more than the rest because all denominations that worship on Sunday apart from Catholics are Protestants and are expected to worship under the umbrella of Protestant churches. While commenting on the large protestant population, a Protestant chaplain in Bungoma prisons said that, "the idea of every sub-denomination among the Protestants having a chaplain is untenable because we are all Protestants and the government may not afford because we are many". While it is not true that everyone is a protestant because of the distinctive nature of doctrinal interpretation and teaching (Protestantism.co.uk, 2018) the words spoken by this protestant chaplains reveals the true condition of the religious services offered in Kenyan prisons. The findings suggest that the majority of inmates encountered by most chaplains are Christians. This results collaborate with Phew research Centre (2012) which observed that on average, the chaplains surveyed say that Christian groups make up about two-thirds of the inmate population, with Protestants, on average, estimated to comprise $51 \%$ of the inmate population, Catholics $15 \%$ and other Christian groups less than $2 \%$. The median estimate by the chaplains of the portion of Protestants is $50 \%$, meaning that half of the chaplains estimate that Protestants comprise more than $50 \%$ of the inmate population where they work, and half of the chaplains estimate the figure to be below that. Compared with Christians, other religious groups are seen by the chaplains as considerably smaller in size. Altogether, non-Christian religious groups are seen as comprising about $18 \%$ of the state prison population. On average, the chaplains surveyed say that Muslims make up about $9 \%$ of the inmate population in the prisons where they work, with half of the chaplains saying that Muslims comprise $5 \%$ or less of the population and half saying Muslim inmates make up more than $5 \%$ of the inmate population. Other non-Christian groups are perceived as considerably smaller in size $(0$ to $1 \%$ for about half of the chaplains responding). Furthermore, according to the chaplains surveyed, inmates with no religious preferences appear to be a smaller minority. Inmates from various denominations are not getting the specialized services they deserve and this calls for reforms in the pastoral programs being provided in these prisons.

Table 3. Denominations of inmates in Western Kenya Prisons

\begin{tabular}{ccc} 
& Frequency & \% \\
\hline Catholic & 74 & 24.6 \\
\hline Protestant & 183 & 60.8 \\
\hline SDA & 44 & 14.6 \\
\hline Total & $\mathbf{3 0 1}$ & $\mathbf{1 0 0 . 0}$
\end{tabular}

Source: Field data

The findings collaborated well with the researcher's observation wherein one of the prisons in Western Kenya counties, a chaplain spent only 30 minutes with the inmates and left to join the community church near the prison. When the researcher wanted to know where he 
was going the chaplain responded that he was rushing to join the lesson discussion. Unfortunately, the Chaplain left even before the 2 hours the inmates are given to worship had elapsed. In another prison, the researcher found 11 catholic inmates worshiping alone inside one of the wards. In that same prison, another group of Protestant inmates was worshiping behind one of the wards without their chaplain. They explained that the chaplain was not available and they were not aware when he would be.

From observations, the researcher noted that, in the prisons that had two chaplains from different denominations, one chaplain attended to condemned inmates and the other attended to long term incarcerated inmate doing time. In prisons where the chaplain focused on the LTCI, the remands were forced to mix with the condemned prisoners for worship. Different categories of inmates differ in terms of their needs and attitudes. Being in remand does not mean that one is convicted. It means that they are simply not able to pay the bail or they are simply awaiting mention, hearing, and determination of their cases. Mixing the remand prisoners with condemned prisoners exposes them to violence, anxiety, powerlessness, trauma on top of the normal prison challenges that inmates undergo. This situation further confirms the diversity existing in these prisons and presents to policy makers the need for more comprehensive pastoral programs in the prisons of the Western Kenya counties.

On the importance of chaplaincy in prisons, Wambugu (2014) pointed out that chaplaincy in its mandate promotes the Biblical model which underlines rehabilitation rather than punishment and revenge. It is argued that punishment does not lead to individual and societal transformation. However, this leads us to another question, if the New Testament discards punishment without providing a solution, how is rehabilitation going to be achieved? King Solomon, reflecting on his parenting beliefs with respect to his own son said: "he that spares the rod hates his own son" (Proverbs 13:24.). According to Rubin (2001), the Pre-Enlightenment society regarded people as existing for the benefit of others, and equally treated the criminal as an outcast and as someone who can be exiled or ignored. Modern society however, sees every person as an equal member of society with inherent rights that cannot be taken away. Consequently, it seeks a mode of punishment that will enable the wrongdoer to return to the community and live a productive life. Additionally, the new psychology propagates a belief that life is no longer to be viewed as a prelude to eternal bliss or damnation, nor punishment as a means of obtaining a confession that would save the wrong-doer's soul (Gray, 1977; Habermas, 1985). From these studies, life is seen as a self-contained set of experiences, with its own course of development. Therefore, punishment must then be vied as an event in that development whose objective helps man to achieve rehabilitation (Rubin, 2001). It can therefore be argued that punishment is a necessary ingredient in proper rehabilitative measures. However, when punishment is administered for whatever reason, it must be given within parameters of correcting and not creating enmity or hardening prisoners.

Chaplains by their specialized ministry are better positioned in understanding prisoners, "spiritual predicaments and relevant rehabilitation". This was derived from the following statements from the chaplains:

Chaplain 7: "We are better positioned to understand issues to do with prisoners especially the spiritual nourishments......."

Chaplain 9: "We believe that we are best placed to address issues of criminality and how to get out of it....."

The late Mandela, a former prisoner and Ex-President of South Africa, is reported in Coyle (2005:15) remarking, that no-one truly knew a nation until one had been inside the prison. A nation should not be judged by how it treats its highest citizens but it's lowest ones, in reference to prisoners. Chaplaincy is crucial in approaching issues of criminality among prisoners as captured in statements from the chaplains above. When prisoners are locked up and isolated, it becomes a natural inclination for them to look for God. Saint Augustine's Confession (in Ferguson 1988) notes that the hearts of human beings are restless until they find rest in God. Same sentiments are made by a prisoner as quoted in Gerland (1991, 1985:24) "That, when you are stripped of your freedom, your job, your family, you begin to seek your purpose in life, and through that, you find someone greater than yourself-God."

Chaplaincy carries out prisoners' rehabilitation process within an ethical framework. This is done based on ethical teachings from scriptures of various denominations. Although this framework is not clearly outlined by the Kenya Prisons Services. Without such a consideration any method of rehabilitating prisoners is subject to ultimately fail. Bartollas (2002) argues that prisoners' "religion is one value which remains constant in their life". It is thus, critical for chaplains to ensure that spiritual care is provided to prisoners in all stages of their moral development. Dankwa (2008) asserts that all human beings require an experience of God in order to love and be loved, an endeavor that chaplaincy stands as potentially reliable. Unfortunately, this has not been the case, as the majority of chaplains have not taken proper theological training, thus their engagement with prisoners leaves so many questions unanswered.

This finding revealed that, some prisons allowed capital offenders and ordinary offenders to interact during worship while in others they worshiped separately. The mixing of offenders of different categories was minimal and limited only to worship services which may have led to others with lesser crimes being influenced by those with higher crimes, thus not achieving the aim of rehabilitation. In addition, the study revealed that inmates rarely saw the chaplain during the week and even worship days except on special occasions or when he is scheduled 
to preach, otherwise the programs are conducted by spiritual leaders. The findings also revealed that the spiritual needs of inmates are not properly addressed because the chaplains are too few to handle the high numbers of inmates. The chaplains do not always meet the inmates when they need their services.

\section{Qualifications of Chaplains}

The vast majority of chaplain positions require post-secondary education. This requires a minimum education requirement, the credentials or certification necessary will involve some additional hours of accredited religious education. A bachelor's degree in religion, religious studies, bible studies, theology or a similar program will most likely be the baseline requirement of education in order to be eligible for a chaplain position. For one to obtain a job as a chaplain, one need an explicit endorsement from the area of faith. Obtaining an endorsement is not a simple matter of asking permission, either. Most religious institutions require demonstrable ministry skills before they are willing to second one of their own as a prison Chaplain. Table 4 presents the educational qualifications of the chaplains as of the time of study.

Table 4. Educational Qualifications of Chaplains

\begin{tabular}{ccc}
\hline & Frequency & $\mathbf{\%}$ \\
\hline Primary & 1 & 6.3 \\
\hline Secondary & 11 & 68.8 \\
\hline Diploma & 2 & 12.5 \\
\hline Graduate & 2 & 12.5 \\
\hline Total & $\mathbf{1 6}$ & $\mathbf{1 0 0 . 0}$ \\
\hline
\end{tabular}

Source: Field data

Results established that 11 (68.9\%) chaplains only had a secondary school certificate as a qualification to be chaplain in prison in Western Kenya Counties, 2 (12.5\%) chaplains had a diploma training while 2 (12.5\%) more chaplains had bachelor's degree. There was $1(6.3 \%)$ chaplain whose qualification was primary school certificate. The requirements for becoming a prison chaplain vary from state to state and from prison to prison. However, there are many common requirements that all candidates should be aware of. In short, it is necessary to have a bachelor's degree, become ordained, and become certified in order to hold this position. Many prisons may require a chaplain to hold a master's degree, especially those that house large populations or have inmates who have committed very serious crimes. The educational path for anyone interested in becoming a prison chaplain will start with earning a bachelor's degree in religion or a related field. Most opt for religion because many programs offer programs tracks aimed at educating new chaplains. These tracks focus on courses such as interpersonal communication, Biblical counseling, and more. They provide a future prison chaplain with the foundation needed to counsel those whose life circumstances are unlike the average member of the congregation (Pastoral Counselling.org., 2019). The role of state prison chaplain demands that he chaplain have an extensive knowledge of many different beliefs and practices, and is able to suspend personal judgment and be respectful of many other faiths and religions. Although each state has distinct educational requirements, most states require that a chaplain hold a degree from an accredited theological school or seminary. The degree is generally a Master of Divinity or similar degree with credits in religious studies, pastoral care, comparative religions and ministry theology. Most states require that the chaplain be an ordained priest, minister or rabbi and many require certification granted by the American Association of Pastoral Counselors (AAPC). Many states require prison chaplains to have at least two years of ministerial experience in a church or other setting before entering prison chaplaincy (Dyer, 2019). Although certification is not required across the board in most Western Kenya Prisons to be hired as a prison chaplain, it does give you a level of professional credibility to be certified-and, as the field becomes more professionalized, certification is likely to be more sought after in hiring.

\section{Training Experiences of Chaplains}

Training of Prison Chaplains require theological professional training which is very significant. A trained prison chaplain equipped with adequate knowledge and skills is able to deliver services more efficiently and effectively to the prisoners. Table 5 presents data on the training experiences of the prison chaplains.

Table 5. Training Experiences of Prison Chaplains

\begin{tabular}{ccc}
\hline & Frequency & $\mathbf{\%}$ \\
\hline Certificate in Bible and Theology & 1 & 6.3 \\
\hline Catechistical Certificate & 1 & 6.3 \\
\hline Certificate Counselling & 1 & 6.3 \\
\hline Church Administration & 5 & 31.3 \\
\hline Certificate Chaplaincy & 1 & 6.3 \\
\hline Christian teaching 1 & 1 & 6.3 \\
\hline Diploma in Discipleship & 2 & 12.5 \\
\hline Degree in Counselling & 1 & 6.3 \\
\hline First Aid & 1 & 6.3 \\
\hline Religious Course & 1 & 6.3 \\
\hline Bachelors in Theology & 1 & 6.3 \\
\hline Total & $\mathbf{1 6}$ & $\mathbf{1 0 0 . 0}$ \\
\hline
\end{tabular}

Source: Field data

Results revealed that $1(6.3 \%)$ had a Certificate in Bible and Theology; another 1(6.3\%) chaplain Catechistical Certificate; $1(6.3 \%)$ had trained and qualified with a Certificate in Theology to serve as a prison Chaplain in Western Kenya Counties. 5 (31.3\%) chaplains had trained as church administrators, $1(6.3 \%)$ chaplain had a 
Certificate in Chaplaincy; another $1(6.3 \%)$ one more chaplain had Certificate in Christian Teaching 1, while $2(12.5 \%)$ of chaplains had diplomas in Discipleship. $1(6.3 \%)$ other Chaplain trained in First Aid, another $1(6.3 \%)$ had a training in some religious course and only 1 (6.3\%) of the chaplains had a degree in Theology. Chaplains and prison warden said during FGDs asserted that; "Rehabilitation of inmates can only begin to happen if theological institutions and universities developed a curriculum that can train them to be effective prison chaplains. Some commented that they were doing guess work as far as rehabilitation of inmates is concerned". The results revealed that most of the chaplains require knowledge and skills in habitation to enable them handle the inmates more effectively. It is important to acknowledge that prison chaplaincy is "a professional discipline, requiring extensive training beyond that of one's own faith group" (Friedman, 2003).

This view was echoed by one OIC who noted that the prisons do not have a vote head to enable spiritual leaders attend seminars and workshop or undertake refresher courses. It was noted that most of the prison chaplains were sponsored for training by their mother churches. The study further revealed that although majority of the chaplains are holders of diploma in Theology, they are unable to express themselves effectively in both the national language (Kiswahili) and English the official language. This is a challenge to effective communication to the inmates.

In his views, OIC $3(03 / 13)$, stated that if the officers who come in contact with prisoners on a daily basis, both junior and senior officers are not people of integrity who are well educated and specifically trained for the job they do which also requires an in-depth understanding of human behaviour, human motivation, human worth and human destiny then it is not possible for them to rehabilitate the offenders. When asked what qualified them to be spiritual leaders in prisons, chaplains cited some training as shown in Table 4. above which revealed that most of the chaplains who had neither trained on Chaplaincy nor a course related to the rehabilitation of inmates were still posted by the Kenya Prison Service to prisons in Western Kenya Counties to help in the rehabilitation of inmates. In fact, only 3 out of the 16 chaplains interviewed had a certificate on chaplaincy or a course related to chaplaincy. Five chaplains had trained as church administrators, a qualification that is not sufficient for a chaplain dealing with inmates. Another interesting qualification was where a chaplain had qualified as a first Aider but was deployed to aid in the rehabilitation of inmates.

These findings show that most of the prison chaplains are poorly or inadequately trained and as such they lack knowledge and skills necessary in addressing the needs of inmates. Majority of the Chaplains were highly educated, with approximately $78 \%$ having some post-secondary education and $47 \%$ having a 4-year degree or more (Tewksbury and Collins, 2005). At this point, the study fills the gap for the need to expose the current state of chaplains in prisons that was called for by Klare (1966) and Mushanga (1974). An understanding of how knowledgeable and skilled the prison chaplains are is important in assessing the effectiveness of pastoral programs of rehabilitation. As noted by Mushanga (1974), knowledgeable prison officers are key for rehabilitation because they can establish the aetiology of antisocial behaviour and apply the correct treatment techniques. Mushanga further recommends that:

Prison guards and Chaplains must be better educated even than judges, for while a judge may be involved in determining whether or not the suspect violated the law, a work that may take hours or days or even weeks, it is the prison guard and chaplain who are charged with the task of reforming the convict year in year out.

Wambugu (2014) noted that proper training of chaplains through advanced increase of information on what chaplains do is crucial in effective rehabilitation of prisoner. Currently, there is virtually no evidence on how well chaplains work, neither is there, an indicator on their impact to prisoners whom they are directly engaged with. With quality being such a central issue in rehabilitation, the profession of chaplaincy is challenged to provide convincing evidence for its methods and outcomes. This is especially so a time as now when chaplains just like other civil servants are expected to work on bases of performance contracting. The present article therefore gives a glimpse of the cadre of chaplains in prisons in Western Kenya. The main observation is that the chaplains lack adequate training to deal with the rehabilitative needs of inmates in Western Kenyan Counties.

\section{Ordination of Chaplains}

Ordination of Prison Chaplains is important as it permits the minister to perform church rites and sacraments, such as baptisms, legal marriages and funerals. An ordained Prison Chaplain is better placed to handle inmate's spiritual and psychological needs than an ordained one. Table 6 presents data on the status of ordination of the chaplains.

Table 6. Ordained Chaplains in the Prison of Western Kenya Counties

\begin{tabular}{ccc}
\hline & Frequency & $\%$ \\
\hline No & 13 & 81.3 \\
\hline Yes & 3 & 18.8 \\
\hline Total & $\mathbf{1 6}$ & $\mathbf{1 0 0 . 0}$ \\
\hline
\end{tabular}

Results reveal that only $3(18.8 \%)$ chaplains are ordained ministers of the gospels whereas $13(81.3 \%)$ are not ordained. This meant that ordinances like baptism and Holy Communion were only possible when an ordained minister from around the community near prisons makes himself available for the ministry. Where no such minister 
was available inmates had to wait until such a time he could come which sometimes took months or even years. A chaplain lamented during the FGDs that "some inmates get converted and get released without ever receiving baptism". Another chaplain asserted:

"He had been preaching for 2 years but haven't had an ordained minister to conduct baptism because the local pastor is also not ordained. But the problem may not be with the churches, one needs to be seconded by the parent church before being appointed as a prison Chaplain, but most of them are trained prison officer who applied to the Kenya Prison Service to be allowed to serve as prison chaplains".

"Prison Chaplain Career Opportunities" (2013) shows that prison chaplains must complete an undergraduate degree from an accredited college or university and a Master of Divinity degree or equivalent from an American Theological School-accredited residential seminary or school of theology. Chaplains must also be ordained or members of a church have at least two years' experience as a ministry leader and are certified through the recognizing endorsing body of his particular faith before being appointed as chaplains in prisons. The findings of the present study revealed that chaplains are deployed to serve in prisons without being seconded by their parent churches. Prison chaplains who are not ordained cannot perform these functions. Having prison chaplains who are not ordained means some inmates get converted but leave prison without receiving the religious rites like baptism to cement their conversion. The above observation that $81.3 \%$ of the chaplains are not ordained could be due to the fact that most volunteers in prison chapel programs come to their work with minimal formal training for the tasks they are expected to perform. Although two-thirds of the volunteers report that they have been ordained, a majority lacks a formal education to prepare them for their duties. As evidenced only one-third of the volunteers have a university/seminary degree and slightly more than one-quarter $(26.8 \%)$ have participated in a mentoring or apprenticeship program. Most common among these volunteers $(82.9 \%)$ is the belief that they have learned to do their tasks through "many" years of experience in the Ministry of Work. With regard to the tasks they perform, there is little difference between ordained volunteers and non-ordained volunteers. Almost all volunteers report that they engage in teaching inmates, with the most frequent formal activity being preaching. Additionally, less than $20 \%$ of all volunteers report engaging in non-religious tasks such as counseling regarding personal problems, assisting with transition/re-entry to society, or providing companionship/friendship to inmates (Tewksbury and Collins, 2005). Previous researchers noted that although prison chaplains have a well-established history of playing a crucial part in the rehabilitation of inmates, most of them find it hard to perform religious rites to those inmates who want them. This is the case in the prisons of the Western
Kenya counties. Being unordained inevitably impacts upon not only how the prison chaplain perceives their own role and identity; but also on how those they serve (prisoners and prison staff) experience and consequently perceive them (Sundt et al., 2002).

Tewksbury and Collins (2005) further note that an examination of the tasks that prison chapel volunteers perform in light of their education and training revealed both expected and unexpected findings. Surprisingly, a comparison of self-reported tasks by volunteers who are ordained and those who are not shows little difference in their activities. The majority $(81.5 \%)$ of ordained volunteers reported preaching at the prison; however, so, too, did one third $(35.7 \%)$ of non-ordained volunteers. Additionally, ordained volunteers were more likely to counsel inmates regarding personal problems (44.4\% vs. $21.4 \%$ ) and spiritual issues ( $77.8 \%$ vs. $28.6 \%)$, and work to convert inmates to their faith $(25.9 \%$ vs. $7.1 \%)$; non-ordained volunteers were more likely to work with inmates regarding society re-entry issues $(28.6 \%$ vs. $11.1 \%$ ).

It is therefore imperative that the government of Kenya collaborate with higher institutions of learning so that they can offer theology in order to develop externship programs for students interested in embarking on a career as a correctional chaplain. The benefits from such programs will enable the students receive hands-on experience working with inmates in a correctional setting, while administrators will receive qualified and much-needed assistance in providing religious programs to inmates.

\section{The Salary of a Prison Chaplain}

Salary is very important to any professional offering services. The Prison Chaplains have families to take care of and other dependents. Furthermore they need finances to meet their daily needs with regard to shelter, food and clothing. The prison chaplains were requested to give details on their remuneration and Table 7 presents data on the average remuneration for the chaplains.

Table 7. The Average Chaplain Salary

\begin{tabular}{ccc}
\hline Salary (KES) & Frequency & $\mathbf{\%}$ \\
\hline Below 20000 & 4 & 25.0 \\
\hline $20000-30000$ & 4 & 25.0 \\
\hline $30000-40000$ & 8 & 50.0 \\
\hline Total & $\mathbf{1 6}$ & $\mathbf{1 0 0 . 0}$ \\
\hline
\end{tabular}

Source: Field data

Results show that the Chaplains emolument were as follows; 4 (25.0\%) chaplains earned below Kshs. 20,000, while another $4(25.0 \%)$ earned between Kshs. 20,000 $-30,000$ per month. Half of the Chaplains interviewed earned between Kshs. 30,000- 40,000 per month. Dyer (2019) states that salaries for state prison chaplains vary from state to state. Chaplaincy came into being in situations 
where pastoral and spiritual care were deemed valuable to help people in the military, hospitals, and prisons cope in crisis situations (Akih and Dreyer, 2017). The role of chaplains and the nature of their work in the military and hospitals is well documented (Paget and McCormick, 2006:3), but the state of prison chaplaincy especially in Africa and Kenya in particular remain undocumented. Roberts (2012:22) says prison chaplaincy requires a specific set of skills and an understanding of the prison environment and system as well as of the people who are incarcerated and those who work there. Lewis (2017) noted that Prison chaplains play an important role in the rehabilitation of incarcerated individuals. These chaplains conduct religious services and provide spiritual counsel. The Bureau of Labor Statistics lists the salaries of prison chaplains with the salaries of other clergymen nationwide in its Occupational Employment Statistics report for 2010. Prison chaplains typically work for state governments, but some are employed by the federal government as well. The average salary of prison chaplains working for state government agencies was $\$ 52,400$ per year, as of May 2010 , according to the Bureau of Labor Statistics.

This study endeavored to bring out the work conditions of chaplains in the prisons of Western Kenya Counties. Knowing how chaplains are paid in particular is important because it will help policy makers legislate laws that will address pay parities of those who offer pastoral care in Kenyan prison.

\section{Places of Worship}

The study explored whether or not there were specific places (rooms or buildings) designated for worship in the Kenya Prisons of Western Region. The responses obtained from 16 chaplains who were interviewed in this subject are shown in Table 8.

Table 8. Places of Worship in Kenyan Prison in Western Kenya

\begin{tabular}{ccc}
\hline & Frequency & \% \\
\hline No & 11 & 68.8 \\
\hline Yes & 5 & 31.3 \\
\hline Total & $\mathbf{1 6}$ & $\mathbf{1 0 0 . 0}$ \\
\hline
\end{tabular}

Source: Field data

Results show that $11(68.8 \%)$ chaplains indicated that the prisons did not have a place of worship from where they could meet the inmates and conduct services. Five (31.3\%) chaplains had returned a positive response that they had a hall of worship. This shows that majority of the inmates did not have a proper place from where they could worship God and listen to their pastors offer the pastoral programs. It also means that service delivery was hampered because inmates could not sit in the sun for long nor attend pastoral programs during the rainy seasons.

Interviews with the officer-in-charge (OIC) manning the Prisons of Western Kenya counties revealed that inmates and Chaplains had a difficult time during worship services. They noted that their major challenge is a place of worship. It's never easy to concentrate to what is being preached while sitting outside and in the sun. It's worse during the rainy season; sometimes inmates do not worship at all. They further stated that their hall of worship is very small and can only accommodate a maximum of 100 people squeezed together. Consequently only a few attend worship. That all the inmates worship together whether on capital, jail or remand basis. Most inmates enjoy prayer time since it gives them some freedom from the normal routine. On Saturday all inmates congregate with Adventists, and on Sunday, all inmates congregate together for worship. Catholics and Protestants alternate on the days of worship. For example the Catholics can lead worship this week, the Protestants will also lead next week. It was further noted that even the Muslims and other religions inmates join the Christians on the day of worship.

During FGDs, chaplains made similar observations. One chaplain mentioned a case where some inmates went for months without getting a chance to worship due to lack of worship facilities. This is the case because most prisons do not have places for worship and even for those that have places designated for worship, the room capacity is often small and only a certain number of inmates can worship at a time on a first come first serve basis. A similar observation was made by an inmates who confirmed that the prison wardens determines who will attend worship by Saturday due to limited spaces of worship. It was observed that in some prisons not all inmates desiring to worship were allowed to attend worship services during their day of worship. It was upon the prison guards to determine who goes to worship and who would stay indoors. Another chaplain further reiterated that the only time all inmates attended worship service was during public crusades and during this time, enough security arrangements were required. In most cases, however, the officer on duty determined those to attend worship services. The Kenyan constitution provides for freedom of religion and allows individuals or communities to manifest any religion through worship, practice, teaching, or observance. According to the constitution, individuals are not to be compelled to act or engage in any act contrary to their belief or religion (Kenyan Constitution, 2010 Chapter 1, Cap 32).

Although forcing inmates to stay indoors is a violation of human freedom to worship, some prison guards perceived limiting the number of inmates who go to worship as necessary in ensuring good behavior and discipline among the inmates since it's not in order to have all inmates attend church services at once. There has to be some restrictions on their movements and association to maintain discipline. It was also clear from observation schedules that when the chaplain had not come to lead the services, inmates worshiped from their wards led by their spiritual leaders. These data provide evidence of genuine worshippers who 
are denied their right to worship at the expense of wanting to maintain discipline. Denying inmates a chance to worship is like denying them an opportunity to transform their lives for better. Rehabilitation of inmates therefore fails to achieve its effectiveness. Consequently, denying inmates an opportunity to worship is denying them their freedom to religion, the prison guards urged that limiting the numbers of worshippers helped them maintain discipline in the prisons. The case of denying inmates their right to worship at the expense of security concerns needs a further investigation.

Another consequence for not having places for worship in the prisons of Western Kenya Counties is brief worship. Lack of places of worship forces inmates to worship outside in the sun and so the services are shortened so that people can run away from the hot sun. During rainy seasons, pastors were forced to suspend worship services completely. In one prison, it was also noted that inmates did not have pews or even benches to sit on during worship. This kind of environment contradicts the Kampala Declaration on Prison Conditions in Africa (1996) that 'the prisoners should retain all rights which are not expressly taken away by the fact of their detention'. Furthermore, those regional instruments demand, in various formulations, that the suffering inherent in imprisonment shall not be aggravated by the regime in prison. The Declaration addresses issues concerning prison conditions, remand prisoners, prison staff and alternative sentencing, as well as making recommendations for the African Commission on Human and Peoples' Rights and setting out an agreed Plan of Action. The European Prison Rules. 2006: Rule 5 specifies: 'Life in prison shall approximate as closely as possible the positive aspects of life in the community'.

In another prison, some inmates stood the whole duration of the service while others sat on the floor and in another prison inmates sat on the floor along the veranda. In all of the five prisons in Western Kenya Counties the situation in worship halls was the same. Inmates worshipped in conditions that were not conducive as many of them moved to and from the nearby toilet and it was clear that they found it hard concentrating on the sermon due to the discomfort caused by lack of seats and tables. This article therefore shows that there are poor worship conditions in all the five prisons of the Western Kenya Counties. First, there is lack of places for worship and in prisons where these facilities are available, they are too small and lack facilities like seats and tables. Lack of seats in the worship halls affected the delivery of pastoral programs because it was uncomfortable for inmates to stand or sit on the floor for the 2 hours which was the duration of all the services conducted in the prisons of Western Kenya Counties. Furthermore, lack of adequate space for worship meant that some inmates would be denied an opportunity to worship because of the first come first serve formula discussed in this section or that inmates with different religious affiliations would congregate together or alternate services so that if for example the Catholic chaplain gives mass on one weekend, the Protestant will lead the services the following weekend. The problems of poor concentration during worship services, limited access to worship services, congregating different denominations together or alternating worship services might compromise the effectiveness of pastoral programs in rehabilitating inmates into better human beings. The Western Kenya Prisons situation differs with the USA prisons (Methodist Church, 2019) where many jails and prisons have chaplains and are able to offer religious programs for inmates. However, typically, religious programming in a jail is fairly limited because of lack of space and lack of the security staff that would be required to oversee the classes and/or worship services. Most state and federal prisons have a chaplain or educational director that manages religious and/or education programming for prisoners. Some prisons have extensive programs for inmates and others do not. It largely depends on the administration's viewpoint on the value of religious programming and whether there are enough correctional staff and volunteers to operate the programs. Lack of space can also be an issue. At the heart of the Chaplain's ministry is worship. Chapel services are often well attended, sometimes by men and women who have never previously attended church. The sanctuary of the chapel, combined with the devotion of liturgy and prayer offers a respite from the rigors of prison.

In some ways, the chapel stands apart from all other places within the establishment as a place of hope in the midst of despair, of forgiveness in a place of punishment and the restoration of life in a place which, for so many, feels like a dead end. Worship provides an opportunity for men and women to be lifted above their circumstances into the liberating world of faith and love (The Methodist, 2019).

Therefore lack of worshipping space in Kenyan prisons is an issue which should be addressed by the Kenyan Government hence provide adequate worship space or chaplains to cater for inmates spiritual needs.

\section{Chaplaincy Offices}

The study sought to know if chaplains had offices from which they could meet with inmates or prison staff wanting to see them for one on one counselling sessions. As shown in Table 9, $15(93.8 \%)$ chaplains do not have offices while only $1(6.3 \%)$ chaplain had an office.

Table 9. Chaplain office in the prisons of Western Kenya Counties

\begin{tabular}{ccc}
\hline & Frequency & \% \\
\hline No & 15 & 93.8 \\
\hline Yes & 1 & 6.3 \\
\hline Total & $\mathbf{1 6}$ & $\mathbf{1 0 0 . 0}$ \\
\hline
\end{tabular}

Source: Field data 
These results implied that inmates have no known place to meet with the chaplains for private counselling. These findings were collaborated by OIC in various prisons within Western Kenya Counties. One OIC complained that one major challenge for the chaplains is lack of office space. This becomes difficult to account for the whereabouts of Chaplains since they do not have office space. It was further noted that in some areas Chaplains share offices with the Welfare in charge and teachers. This makes it difficult for them to effectively and efficiently discharge off their duties. It was observed that even those who shared offices with other sectional heads did not have comfortable chairs, they sat on benches. Furthermore most offices lack stationary like files, notebooks or papers and other relevant office equipment. This greatly affected service delivery, record keeping consequently kept the chaplains demoralized.

Chaplain are deployed within the prison environment to exemplify Christ's humility and servant hood among his people; an example of God's infinite love and transforming grace. The chaplain's presence and visibility in cell blocks, exercise yards, and other prison areas, conveys the meaning that the church desires to be with them and cares about their welfare (Covert, 1995; Schilder, 1999).

It can be concluded that, although the government has employed chaplains to work, provide spiritual nature and help rehabilitate inmates, it has not facilitated them with infrastructures necessary to work effectively. It was also revealed that inmates only met with their pastors during open meetings which are not sufficient for those who want to do a follow up on what had been preached or those wanting to have a private conversation with the pastor. Lack of offices and a known program when inmates could see their pastors worked against the chaplains in their efforts to rehabilitate inmates.

\section{Counselling Schedule}

The chaplains were asked if they had office schedules when inmates and other prison staff could visit them for counselling during the week. Table 10 shows the chaplains' responses as to whether or not they held office hours during which inmates came for counselling during the week.

Findings show that $14(87.5 \%)$ chaplains in the Prisons of Western Kenya Counties indicated that they did not have known times for their inmate clients to see them for counseling. Only $2(12.5 \%)$ chaplains had known times when they could meet inmates. These findings revealed that the one-on-one counseling sessions were rarely carried out in the said prisons. It therefore, followed that inmates were not properly attended to during the week apart from weekends when the worship program is fixed. These findings are reinforced by inmates during FGD discussions. An inmate in one of the prisons in Western Kenya Counties stated that, "apart from Sundays it's very hard to see our pastor, maybe because they do not have offices but they should be around somewhere during the day for inmates to access their services". They emphasized that it is important for them to receive counselling services since they face many psychological, mental and emotional challenges.

Table 10. Chaplains' Weekly Counselling Schedule for Inmates

\begin{tabular}{ccc}
\hline & Frequency & \% \\
\hline No & 14 & 87.5 \\
\hline Yes & 2 & 12.5 \\
\hline Total & $\mathbf{1 6}$ & $\mathbf{1 0 0 . 0}$ \\
\hline
\end{tabular}

Source: Field data

This finding was supported by one of the OIC who remarked during interviews that the Kenya Prison Service should give a known program on chaplaincy for them to implement. However during the survey in one prison, not a single chaplain was around to meet the inmates during the week. In another prison, the chaplain made a brief appearance during worship service and went back to the community church ostensibly where they enjoyed the services. When probed during FGDs why they left the inmates unattended, that chaplain stated that it was not easy to preach in the hot sun. The researcher further observed in one of the Prisons in the Western Kenya Counties chaplain sitting in a small office that had other officers who identified themselves as teachers and welfare officers. This collaborates with the findings of Allard and Allard (2010) about prisons in Rwanda where prison chaplains go to prisons as often as they can, to meet with the demands of inmates who ask them to provide their physical needs like clothing, tissue paper and medicine. This is sometimes difficult because despite receiving no salary and no transportation allowance, the chaplains still go to prisons although they sometimes have to bribe the guards to let them in which has become standard practice in some prisons where the prison guards themselves have not been paid for a long time.

In the few offices available, there was an incident when one inmate knocked at the door the chaplain shouted "utaniona baadaye sasa niko na wageni" [Please see me later, I am attending to visitors now]. When the inmate insisted that his issue was urgent the chaplain retorted "sema basi" [go ahead and state your problem] to which the inmate insisted "nataka kukuona wewe" [it's you I wanted to see] a conversation that took close to 10 minutes before the chaplain finally moved out and re-emerged after 30 minutes claiming thus "hizi ni story za wafungwa tumezizoa" [we are used to these stories from inmates]. The findings revealed a disorganized and demoralized chaplaincy department that was overwhelmed by the work because of the large population of inmates and the demands to address the needs of inmates. Many chaplains had devised a method of hiding from the role of counselling inmates because they could not supply the inmate's physical needs. It was also 
revealed that other chaplains were too casual on how they handled those who needed to see them. It was also revealed from the findings above that inmates do have private issues that they want to share and that pastors are the most trusted personnel to listen and counsel. Religious services are provided to inmates/prisoners with special emphasis on the moral and spiritual dimensions that will help an inmate/prisoner both now and in the future. Through the Correctional Services Chaplain, Honorary Chaplains and volunteers from religious organizations, a wide range of spiritual and social services are offered to all inmates/prisoners who wish to participate regardless of their religious affiliation. The services include visits, teaching, counseling, religious worship and recreational activities (Sundt, 2002).

The prison chaplaincy service is a multi-faith service and is responsive to all faiths. Prisoners do not need to profess a faith to request help from a chaplain. The chaplaincy service offers a message of hope, reconciliation and healing delivered with dignity and respect. The prison chaplaincy offers: pastoral care - a listening and support services for prisoners and staff, religious services including worship programs and religious education and varying programs that emphasis personal development. All prisoners are given the opportunity to express their faith, to practice their religious beliefs and have access to appropriate sacred texts, rituals and literature. This is with accordance with human rights conventions and security protocols. The chaplaincy also provides a number of programs including individual pastoral care and group work. The prison chaplaincy offers: pastoral care - a listening and support services for prisoners and staff, religious services including worship programs and religious education and varying programs that emphasis personal development. All prisoners are given the opportunity to express their faith, to practice their religious beliefs and have access to appropriate sacred texts, rituals and literature. This is with accordance with human rights conventions and security protocols (Government of Southern Australia, 2014).

Values that chaplains want inmates to learn include humility, respect, patience, and gratitude, all of which are intrinsically religious and come from biblical teachings. The chaplains explained that they explore the potentials or values that inmates possess and encourage them to develop these, and that they teach them how they could contribute to society. Ultimately, they aim to help inmates build or improve their relationships with God, their families, and other people, and from this, to be able to successfully return to society (Chui and Cheng, (2012).

\section{Funding of Chaplaincy in the Prisons of Western Kenya Counties}

The study sought to know who funds the pastoral programs of the Western Kenya counties. The chaplains were thus interviewed as to whether it was the government or the church and Faith-based organizations (FBOs) and well-wishers who funded their programs. Table 11 shows the chaplains' responses to the issue of funding.

Table 11. Who Funds Chaplaincy Programs

\begin{tabular}{ccc}
\hline & Frequency & \% \\
\hline Government & 6 & 37.5 \\
\hline $\begin{array}{c}\text { Churches and FBOs and } \\
\text { well-wishers }\end{array}$ & 10 & 62.5 \\
\hline Total & 16 & 100.0 \\
\hline
\end{tabular}

Sources: Field data

The findings revealed that the Government of Kenya funds some prisons' pastoral programs with $6(37.5 \%)$ chaplains indicating they received assistance. The study revealed that the chaplains received an insignificant and insufficient amount of support from the government to run the pastoral programs. However, $10(62.5 \%)$ indicated that the pastoral programs in the prisons of Western Kenya Counties were supported by the Faith-based Organizations (FBOs) and churches. During interviews, most OIC admitted that they do support the pastoral programs by adjusting other vote heads where possible in order to spare some amount for the chaplaincy departments within their jurisdictions. However some officers in charge of prisons in Western Kenya counties said they had no money to help with the pastoral programs. It was revealed that the government does not allocate any money for the chaplaincy department even though they occasionally receive signals from the headquarters to support this or that program. When that happens it's the officer's duty to sanction expenditure from whichever vote head because they must obey orders from the bosses. Dominey and Lowson (2017) state that the work of community chaplaincy requires adequate and secure funding. When income is uncertain, the expertise of staff and volunteers is lost and organizational energy is diverted away from the development of the service to raising of funds. In Israel, the Senate Commission changed its position and decided to also cover part of the costs for Jewish pastoral care (Robert, 2019). However, interviews from the FGDs revealed that what the chaplains called supports were the periodical visits by churches from the community to supply inmates with the basic needs like soap, tissues and sometimes bibles. One chaplain explained that Churches from the community do shoulder a lot in prison. Some inmates do not have relatives visiting the whole period of their incarceration and even those who visited have their personal effects stolen by those who do not have. This is where the churches support the prison.

One prison guard who introduced himself as assistant chaplain noted that the levels of suffering among the inmates are unbearable sometimes. The only way you can have a sizable number of inmates attending worship services is when visitors come. The inmates know visitors 
come with blessings." On the same note an inmate reiterated during FGDs and confirmed that it was true, the only people who cared about their needs were the church members from outside those walls.

The study further established from observations that several church leaders and members from the community visited the prisons. During one of those occasions in the female prison all inmates received, 3 packets of sanitary towels each, 2 panties each, a bar of soap per person, an orange for everyone and a packet of milk for the children accompanying their mothers in prison. It was observed that the service were lively with all inmates from all the religions within prison participated in singing and dancing to the gospel choruses led by the worship leaders. There were shouts of "Amen" and "Hallelujah" as the preacher spoke the word. However, the following Sunday the service was a quite subdued affair that even though all the inmates were in attendance they were not as lively as when the visitors were there. In the USA Joan Chittister Fund for Prisoners work closely with a network of 90 prison chaplains and volunteers to insure that materials reach those in prison and are used effectively-in small discussion groups, retreats, journal classes, and for individual reflection and prayer. Broadly speaking, religious activities add colour to the boring (and often dehumanizing) prison life and aim to inspire inmates to turn away from a life of crime. As suggested by O'Connor and Perreyclear (2002), most inmates perceive their lives in prison as "meaningless," "difficult," and "bleak". O'Connor (2005) held the view that religious activities play a significant role in humanizing the harsh correctional environment of prisons and in fostering hope among lost and desperate inmates. Religious activities can calm the emotional upheavals of the inmates and promote their own self-awareness, hereby destroying hatred and generating hope and wisdom. Chui and Cheng alludes that chaplains want inmates to learn include humility, respect, patience, and gratitude, all of which are intrinsically religious and come from biblical teachings. The chaplains explained that they explore the potentials or values that inmates possess and encourage them to develop these, and that they teach them how they could contribute to society (Chui and Cheng, 2011).

We further looked at the donations from well-wishers as a potential source of funding. Results revealed that churches also relied on donations since there was no chaplaincy department vote head to enable them facilitate their activities. This negatively affected the functioning of the chaplaincy programs. It was further discovered that due to lack of funding, only one prison had an office. The rest of the $4(80.0 \%)$ prisons the chaplains did not have offices, stationary or storage facilities to record and keep files. In this digital era not a single computer was found even the prison which had an office. This revelation meant that the chaplains were poorly facilitated and majority of them never kept records of their activities in prison.

These findings are in line with the words of Stuart (2007) that the demands of prisons and prisoners is placing increasing pressures on prisons staff chaplains more so because of the populations and the diverse needs of inmates. According to Ndungu (2005) prisons in Kenya, like others in many African countries, are places of disease, poverty and desperation, of violence and corruption. The effect of prisons is deeply negative - drugs and disease spread rapidly, mental health deteriorates, and AIDS spreads. Unfortunately, it is a less equipped chaplain who has to shoulder all that.

\section{Residential Facilities for Chaplains}

The study showed that Chaplain live in extremely dilapidated houses within the prison compounds. In one of the houses, a chaplain had lived in what used to be a carpentry workshop for the past 10 months while he waited to be moved to a better facility. In another house, two married chaplains shared one room separated with a curtain. On the said conditions one of the chaplains confided that it's a shame that most of their colleagues live in some inhuman settlement makeshifts. Some chaplain claimed that; "many of us cannot even allow our families to come here but the brave ones do let them come and when they do you are forced to listen to what they are doing behind the curtains or play your radio loudly." The living conditions are deplorable! The latrines that the prison staff use are equally terrible in one of the prison, the doors were not properly fixed and they were never kept clean. One of the chaplain complained that they only have four toilet holes serving about 50 officers and their families some of whom do not care how they use them. The state of the latrines could easily transmit communicable diseases to the various families affected.

The researcher observed that in some prisons new two bedroom houses had been built for prison officer, but the ranked officers were the ones living there leaving the chaplains who held the lowest rank of a constable to make do with the mad walled or iron-walled old houses. From the findings on the residential areas of Chaplains, it was established that majority of them lived in homes that were run down, old and uncomfortable. Many did not have privacy and were not secure from breakups from neighbors and these left chaplains demoralized and hence it may have affected the delivery of pastoral services.

\section{Conclusions}

The paper has examined the current conditions of prisons in western Kenya. The current educational background of the chaplains, salary, places of worship, lack of adequate and furnished offices, lack of counselling programs and dilapidated housing conditions hinder 
effective and efficient pastoral programs to run effectively to ensure that future crimes are prevented by incapacitation, deterrence, and rehabilitation. Consequently the pastoral chaplains are not able to give inmates realistic plans for their lives, as well as help them overcome shame and guilt and help provide a meaningful human service. Despite the many efforts by the Kenya government on the improvement of prisons living conditions for both the prison officers and the inmates the current conditions of prisons in western Kenya are still deplorable. This requires the realization that according to the signs of our times, for an effective chaplaincy in prisons there is need to improve on the current conditions in all the prisons in western Kenya today.

\section{REFERENCES}

[1] Akih, A., and Dreyer, Y. (2012). Deficiencies in Pastoral Care with Prisoners in Cameroon. HTS Theological Studies, $68(1), 1-7$.

[2] Allard, P., and Allard, J. (2010). Prison Chaplaincy, Restorative Justice and Just.Equipping. Journal of Social Justice, 21 (12), 330-338.

[3] Amoakoh, N. (2012, May 2). Behind Closed Doors: Crimes Agaist Women in African Prisons. Think Africa Press, 1-4.

[4] Bartollas, C. (2002). Invitation to corrections. Boston: Allyn and Bacon.

[5] Black, T. R. (1999).Doing quantitative research in the social sciences: An integrated approach to research design, measurement and statistics. Thousand Oaks, CA: SAGE Publications, Inc.

[6] Borg, M. and Gall, M. (1983). Educational Research: An Introduction. New York: Longman.

[7] Chui, W. H. and Cheng, K. K. (2011). Self-Perceived Role and Function of Christian Prison Chaplains and Buddhist Volunteers in Hong Kong Prisons: International Journal of Offender Therapy and Comparative Criminology 57(2).

[8] Coyle, A. (2005).Understanding Prisons: Key Issues in Policy and Practice (Crime and Justice). London: Open University Press

[9] Covert, G. (1995).Ministry to the Incarcerated. Chicago: Loyola University Press.

[10] Dammer, H. (2002). The Reasons for Religious Involvement in the Correctional Environment. Journal of Offender Rehabilitation, 35 (3-4), 35-58.

[11] Dominey, J. and Lowson, E. (2017).Community Chaplaincy and Desistance: Seeing a New Future: Community Chaplaincy Association, Cambridge University.

[12] Duncombe, D. (1992). The Task of Prison Chaplaincy: An Inmate's View. The Journal of Pastoral Care 46(2), 383390.

[13] Dankwa, V. (2008). Overcrowding in African Prisons. In S.
Jeremy, Human Rights in African Prisons (pp. 93-102). Cape Town: HSRC Press.

[14] Dyer, M. H. (2019). State Prison Chaplain Salaries. Work-Chron.com,

http://work.chron.com/state-prison-chaplain-salaries-1666.h tml. Accessed 07 February 2019.

[15] European Prison Rules (2006). European Prison Rules" Council of Europe Publishing.

[16] Fraenkel, R. and Wallen, E. (1999). How to Design and evaluate Research in Education. $4^{\text {th }}$ Edition. Illinois: F.E. Peacock Publishers, Inc.

[17] Friedman, G. (2003, August). Chaplaincy: Facing new and old challenges. Corrections Today, 65, 90-91.

[18] Garland, David 1985: The Criminal and His Science. A Critical Account of the Formulation of Criminology at the End of the Nineteenth Century, in: British Journal of Criminology 25. 2, 109-137.

[19] Garland, D. (1991).Sociological Perspectives on Punishment Crime and Justice, VoI.14 (1991), 115-165.

[20] Government of Southern Australia. (2014). Chaplaincy and faith services. Department of Correctional services.https://www.corrections.sa.gov.au/Rehabilitation-e ducation-and-work/additional-support/chaplaincy-and-faith -services.

[21] Gray, J. A. (1977). Drug effects on fear and frustration: Possible limbicsite of action of minor tranquilizers. In L. L. Iversen, S. D. Iversen, and S. H. Snyder (Eds.), Handbook of psychopharmacology (Vol. 8, pp.433-529). New York: Plenum.

[22] Habermas, J. (1985). The Philosophical Discourse of Modernity. Twelve Lectures. Cambridge: Blackwell.

[23] Johnson, B. (2008). Not by Gornment nor Faith Alone: Rethinking Prisoner Rentry. Correctional Compendium, 17-38.

[24] Kampala Declaration on Prison Conditions in Africa, Promoting Fair and Effective Criminal Justice (1996). Found in https://www.penalreform.org/resource/kampala-d eclaration-prison-conditions-africa/

[25] Keuther, F. (1951). Religion and the Chaplain. New York: McGraw-Hill.

[26] Korn, R. A. (1959). Criminology and Penology. Sacramento: Holt, Rinehart and Winston.

[27] Kothari, C. (2004). Research Methodology: Methods and Techniques. New Delhi: New Age International Publishers.

[28] Klare, H. (1966).Changing Concepts of Crime and Its Treatment.

[29] 1st Edition, eBook ISBN: 9781483151168, Imprint: Pergamon Published Date: 1st January 1966

[30] KPS (Kenya Prison Service Strategic Plan) (2008-2012).

[31] Lewis, J. (2017). The Salary of a Prison Chaplain. New York: Bizfluent.

[32] McNeill, J. (1951). A History of the Cure of Souls. New York: Herper Torchbooks. 
[33] Milner, A. (2012). African Penal Systems. Indiana Law Journal , 47 (3), 593-600.

[34] Mushanga, T. (1974). Criminal Homicide in Uganda. Nairobi: East Africa Literature Bureau.

[35] Ndun'gu, M. (2005). Land and Graft in Kenya. Nairobi, Kenya.

[36] O'Connor, T. P. (2002). Introduction: Religion-offenders-rehabilitation: Questioning the relationship. Journal of Offender Rehabilitation, 35, 1-9.

[37] O'Connor, T. P. (2005). What works-Religion as a correctional intervention: Part II. Journal of Community Corrections, 14, 4-26.

[38] Pace, D. (1982). Religion Programs in Jail. Corrections Today, 46-49, 76.

[39] Paget, N.K. and McCormick, J.R., 2006, The work of the chaplain, Judson Press, Valley Forge, PA.

[40] Pastoral Counselling.org. (2019). https://www.pastoralcoun seling.org/career/prison-chaplain

[41] Phew Research Centre, (2012). Chaplains' Perspectives on the Religious Lives of Inmates: Religion and Public Life.

[42] Prison Chaplain Career Opportunities, (2013).

[43] Rabey, S. (1999, March 1). Redeeming the Prisoners. Christianity Today, 27.

[44] Remcharan, B. Strategic Plan 2005-2006. Introduction to Human Rights for Commonwealth Prison Officials Draft.

[45] Ristard, R. N. (2008). A Stark Examination of Prison Culture and Prison Ministry. Dialog: A Journal of Theology , 47 (3), 292-303.

[46] Roberts, R.S.B. (ed.), 2012, Professional spiritual and pastoral care: A practical clergy and chaplains handbook, Skylight Paths, Woodstock, VT.

[47] Robert, R. (2019). State Funding for Jewish Prison Chaplains (translated by Insa Kummer), in: Key Documents of German-Jewish History, January 21, 2019. $<$ https://dx.doi.org/10.23691/jgo:article-247.en.v1> [February 08, 2019].

[48] Rubin, E.L. (2001).The Inevitability of Rehabilitation. A Journal of Theory and Practice: Law and inequality. 19(2).

[49] Schuler and Watson. ( 2009 ). Life Long Learning and Crime: An analysis of the Cost Effectiveness of in Prison Educational and Vocational Interventions. IFLL Public Value Paper 2. http://www.niace.org.uk/lifelonglearninginq uiry/published papers. Html accessed 12/09/2012.

[50] Sharp, E. (1977). An Administrator's Perspective on the Chaplain and Religious Programs. Association of Evangelical Institutional Chaplains Journal (4), 2.

[51] Sihombing, B. (2010). Co-operation Among Churches Doing Mission: A Case Study of Prison Ministry in Indonesia. Asia Journal of Theology, 65-79.

[52] Sundt, J. L., and Cullen, F. T. (2002). The correctional ideology of prison chaplains: A national survey. Journal of Criminal Justice, 30, 369-385.
[53] Sundt, J., Dammer, H., and Cullen, F. (2002). The Role of the Prison Chaplain in Rehabilitation. Journal of Offender Rehabilitation , 39, 59-86.

[54] The Kenyan Constitution of 2010 Chapter 4; Article 49.

[55] The Methodist Church (2018). About prison Chaplaincy: The role and responsibility of a prison chaplainhttps://www.methodist.org.uk/our-faith/worship/m ethodist-special-sundays/prisons-sunday/about-prison-chapl aincy/

[56] The New Constitution of Kenya 2010, Section 32.

[57] The Prisons Act, Section 99.

[58] Tewksbury, R. and Dabney, D. (2004). Prison volunteers: Profiles, motivations, satisfaction.Journal of Offender Rehabilitation 40 (1/2), 173-183.

[59] Tewksbury, R. and Collins. S.C. (2005).Prison Chapel Volunteers: Federal Probation. Journal of Correctional Philosophy and Practice: Vol.69, No.1.

[60] Wambugu, P. W. (2014). Chaplaincy and Rehabilitating Prisoners: A Case Study of Embu and Kamiti Prisons in Kenya. Nairobi: Unpublished Thesis, Kenyatta University. 